\title{
ARTIGOS
}

\section{KINETICS OF TRYPANOSOMA CRUZI DESTRUCTION IN THE MOUSE SPLEEN}

\author{
Zulmira M.S. Cordeiro, Ana Cristina Gonzalez Dahia \\ and Zilton A. Andrade
}

\begin{abstract}
Massive destruction of parasitized splenic macrophages was histologically observed at the height of a virulent infection caused by Trypanosoma cruzi ( $Y$ strain) in the mouse. This was coincident with a sudden drop in parasitemic curve. Most of the animals died at this point, probably due to the liberation of toxic products, such as TNF, following the massive destruction of parasitized cells. However, parasitized-cell destruction indicated the transition from susceptibility to resistance. Although it has been extensively studied in vitro, this study contributes with the morphological counterpart observed in vivo by optical and electron microscopy. When infected animals were specifically treated during early infection transition to chronic phase was immediately observed without splenic parasitism. Animals that apparently recovered from massive cell-destruction in the spleen showed evidences of a rapid restoration of splenic architecture.
\end{abstract}

Key-words: Trypanosoma cruzi. Macrophages. Spleen.

During infection of mice with a virulent $\mathrm{Y}$ strain of Trypanosoma cruzi, macrophages appear as the predominant site of parasite multiplication. This macrophagotropism is a prominent feature of Type 1 strains, which include the $\mathrm{Y}$ strain and the Peruvian strain as prototypes ${ }^{1}$.

By sequentially and histologically studying the evolution of a virulent $\mathrm{Y}$ strain infection in young mice, two striking features were observed: a) the progressive increase of macrophage parasitism in the spleen followed by a massive destruction of both macrophages and parasites at the height of infection, which coincided with a sudden drop in parasitemia and which often preceded animal death; b) when mounting splenic parasitism was abrogated by chemotherapy, infected animals survived for prolonged periods of time, splenic parasitism completely disappearing, while chronic infection followed its course. Thus, the dramatic and massive parasite destruction represents a transition from susceptibility to immunity. Although several well-conducted sequential histological studies of the spleen in acute $T$. cruzi infection with the $\mathrm{Y}$ strain have been

Endereço para correspondência: Dr. Zilton A. Andrade. Laboratório de Patologia Experimental, Centro de Pesquisas Gonçalo Moniz/FIOCRUZ. R.Valdemar Falcão 121, 40295-001 Salvador, B, Brasil.

Recebido para publicação em 06/05/96. made, most of the characteristics of this transitional phase here considered have been overlooked $^{25} 9^{10}$.

The present work attempts to investigate by light and electron microscopy the splenic changes leading or preceding the transition from susceptibility to resistance during a virulent $T$. cruzi infection in vivo.

\section{MATERIAL AND METHODS}

White swiss mice, 10/12g, of both sexes were intraperitoneally injected with 1,000 to 20,000 blood forms of T. cruzi in eight series of experiments, each involving about 50 animals. Parasitemia was evaluated daily for the first five groups and, for the other three groups, every other day, starting on day $5^{\text {th }}$. Mortality was very high. Even with small inoculum (5,000 trypomastigotes) mortality was total by the 10-11 $1^{\text {th }}$ day, eventually reaching the $15^{\text {th }} / 18^{\text {th }}$ day in those receiving the smallest inoculum (1,000 trypomastigotes). Animals found dead were discarded. Following inoculation the animals were sacrificed on the $5^{\text {th }}, 7^{\text {th }}, 10^{\text {th }}, 12^{\text {th }}, 14^{\text {th }}, 15^{\text {th }}$ and $18^{\text {th }}$ day.

To avoid high mortality, a group of 95 mice infected with 2,000 to 5,000 trypomastigotes was treated on the $7^{\text {th }}$ day of infection with $50 \mathrm{mg} / \mathrm{kbw}$ of benznidazole daily, during 5 days. They were sacrificed at different periods of time, up to 30 days after infection. Parasitemia was considerably reduced after treatment and 
Cordeiro ZMS, Dabia ACG, Andrade ZA. Kinetics of Trypanosoma cruzi destruction in the mouse spleen. Revista da Sociedade Brasileira de Medicina Tropical 30:3-9, jan-fev, 1997.

remained low thereafter (Figure 1) and the animals presented normal development with no signs of disease.
Sacrificed animals were submitted to complete autopsies. The spleen was weighted. Fragments of the spleen, liver, heart and

a
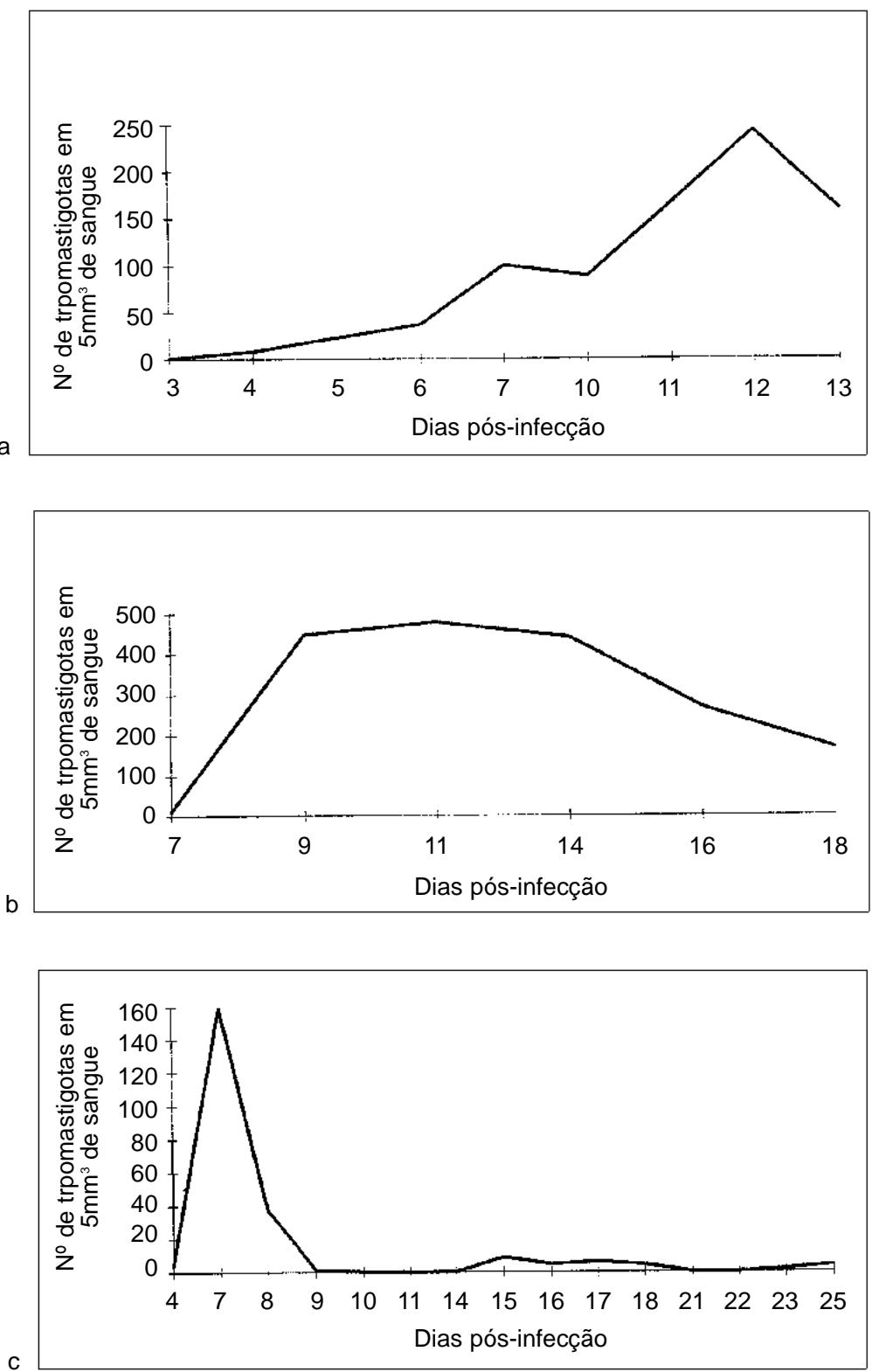

Figure 1 - Parasitemic curves: a) animals inoculated with 20,000 trypomastigotes; b) shows a somewhat less severe course seen in animals inoculated with 4,000 trypomastigotes; c) it demonstrates the effect of treatment, which was administered from the 7 th up to the 12th day of infection. 
Cordeiro ZMS, Dabia ACG, Andrade ZA. Kinetics of Trypanosoma cruzi destruction in the mouse spleen. Revista da Sociedade Brasileira de Medicina Tropical 30:3-9, jan-fev, 1997.

intestines were fixed in neutral formalin (Millonig fixative). and later embedded in paraffin. The sections obtained were stained with hematoxilyn and eosin. Small pieces of splenic tissues were immediately fixed in $4 \%$ gluteraldehyde in $0.2 \mathrm{M}$ sodium cacodylate buffer, $\mathrm{pH} 7.4$, during one hour, post-fixed for one hour in $1 \% \mathrm{pH} 7.4$ osmium tetroxide in $0.3 \mathrm{M}$ cacodylate buffer. These fragments were embedded in 812 polybed resin. The ultra-thin sections were contrasted with lead citrate and $7 \%$ uranyl acetate, and examined under an M9 Zeiss electron microscope at $50 \mathrm{Kv}$.

Parasitemia was performed in a drop of blood obtained from the mouse tail, covered with a cover slip and immediately examined with 40x objective x 10x ocular. One-hundred fields were counted and results were expressed as averages (Figure 1).

\section{RESULTS}

Parasitemic curves are shown in Figure 1.

At light microscopy parasitism of splenic macrophages was detected on day $5^{\text {th }}$ in isolated cells present specially within the marginal zone of the lymph follicles. Occasionally, macrophages in the red pulp also appeared parasitized at this time. Parasitism became more evident from the $7^{\text {th }}$ day on. Amastigotes in cells of the white pulp appeared later $\left(15^{\text {th }}\right.$ day). Progressive accumulation of parasitized cells in the spleen was followed at first by relatively mild changes in splenic histology. Only after the $7^{\text {th }}$ day of infection, three main changes became progressively more constant: hyperplasia of non-parasitized macrophages, depletion of lymphoid cells in the red pulp and activation of germinal centers of the white pulp. Depletion of lymphocytes was probably due to apoptosis, since many of them exhibited cytoplasmic condensation, nuclear clumping, picnosis and cariorrhexis. Non-parasitized macrophages, presented clear and enlarged cytoplasm, tending toward an epithelioid appearance. The center of the lymphoid follicles and the marginal perifollicular zones were expanded and the latter gradually fused with the red pulp. Dark dots, probably nuclear fragments, were frequently found within phagocytes in the center of the white pulp. After the $7^{\text {th }}$ day of infection a few, isolated, parasitized macrophages disintegrated and the liberated amastigotes were seen within the shrunken and vacuolated macrophage cytoplasm or free in the interstitial tissue. This was regularly accompanied by an influx of polymorphonuclear neutrophils, which sometimes were seen with phagocytized amastigotes (Figure 2).

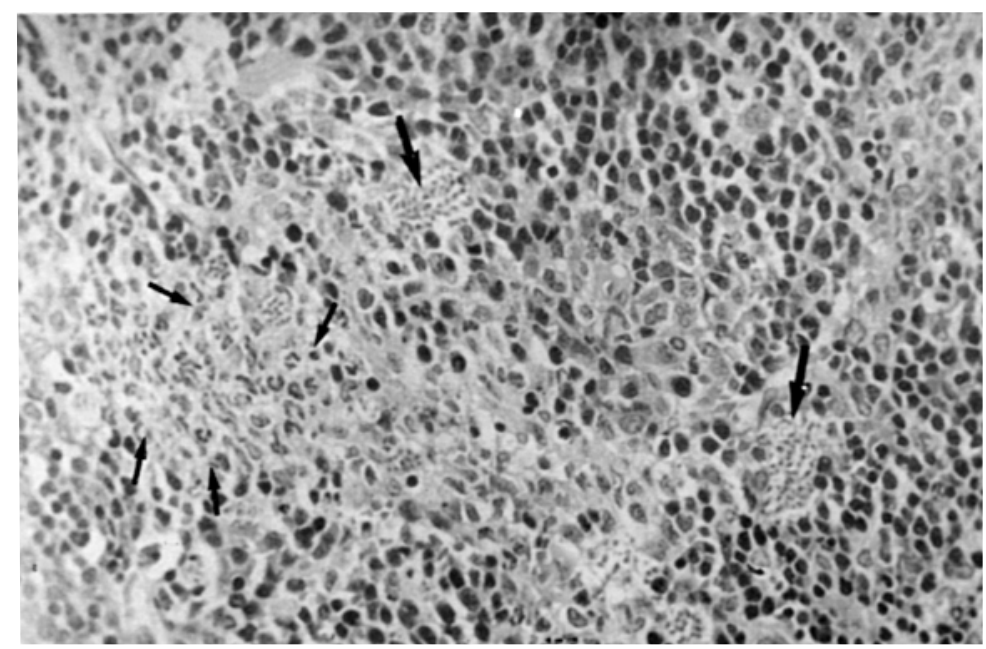

Figure 2 - Infiltration of polymorphonuclear neutrophil leukocytes argund disintegrating parasitized macrophages (small arrows) as observed at the $7^{\text {th }}$ day of infection. Heavily infected but well preserved macrophages are also present (larger arrows). Hematoxylin \& Eosin, $250 X$ 
Cordeiro ZMS, Dabia ACG, Andrade ZA. Kinetics of Trypanosoma cruzi destruction in the mouse spleen. Revista da Sociedade Brasileira de Medicina Tropical 30:3-9, jan-fev, 1997.

Macrophage parasitism, lymphoid-cell depletion and macrophage hyperplasia became accentuated in the following days. However, the most striking change was observed around the $12^{\text {th }}-15^{\text {th }}$ days when intracellular parasitism was at its highest point. Then, all parasitized cells appeared swollen, fragmented, containing disintegrating parasites (Figure 3). No polymorphonuclear leukocytes were seen at this time, when a single parasitized macrophage could ever be detected, even after a thorough search of the histological sections. As indicated before these changes were coincident with a sharp decline in parasitemic curve and this event was regularly followed by the death of the animal.
Macrophages in the liver (Kupffer cells) also contained amastigotes and revealed the same changes observed in splenic macrophages (Figure 4). However, sections of the myocardium showed well preserved parasites within myocytes at the same time parasitized cells in the spleen and liver were undergoing destruction (Figure 4).

Some animals were sacrificed next day after parasitemic drop and so the degradative changes could be analyzed by electron microscopy. Then, every intra and extra-cellular parasites showed evidences of degradation (Figure 5). Amastigotes were found within the cytoplasm of disintegrating macrophages or free in the interstitial tissue. In both cases they exhibited

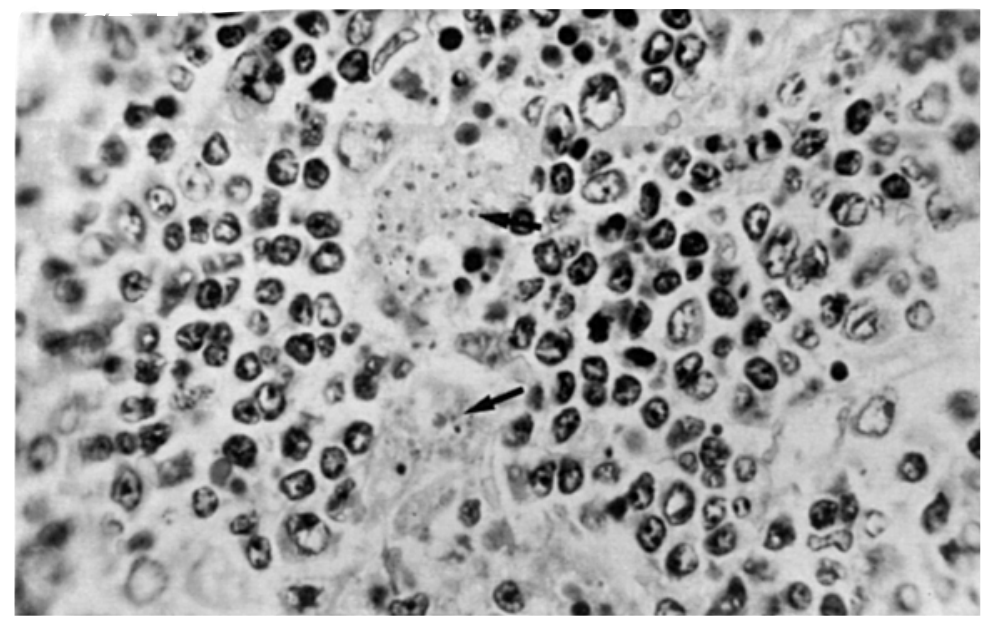

\begin{abstract}
Figure 3 - Aspect of the red splenic pulp during the phase of massive cellular destruction. Parasitized macrophages appear swollen, pale and vacuolated. Internalized parasites exhibit irregularities in nuclear size and staining (arrows) Hematoxylin \& Eosin, 400X.
\end{abstract}

nuclear and cytoplasmic degenerative alterations. They usually presented an irregular outline and shrunken, dark, vacuolated cytoplasm and nuclear picnosis or cariorrhexis (Figure 6). The kinetoplast/mitochondrial complexes were markedly swollen and/or vacuolated. All parasitized macrophages were partially or totally destroyed, but the non-parasitized ones appeared normal. Frequently aggregated and partially degranulated platelets were observed within splenic capillaries (Figure 7), which showed excessive signs of pinocytosis and irregular vacuolization. Sometimes cells with the characteristics of myofibroblasts (fusiform cells with dark submembranar contractile apparatus) exhibited focal proliferation, forming clusters in the middle or in close proximity to disintegrated macrophages. (Figure 8).

Two animals survived up to the $18^{\text {th }}$ day of infection, 4 days following parasitemic drop. One was agonizing, but the other seemed in fair condition. No parasites were seen in their spleens, but numerous viable macrophages containing nuclear and other debris within the cytoplasm were observed. Lymphoid-cell 
Cordeiro ZMS, Dahia ACG, Andrade ZA. Kinetics of Trypanosoma cruzi destruction in the mouse spleen. Revista da Sociedade Brasileira de Medicina Tropical 30:3-9, jan-fev, 1997.

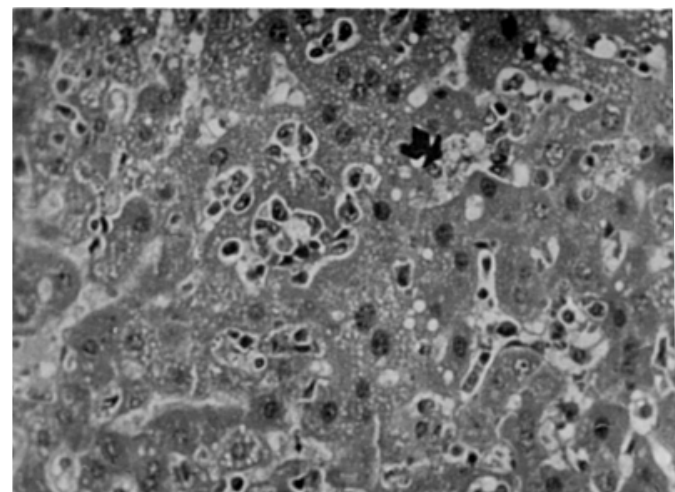

Figure 4 - Parasitized macrophages inside the bepatic sinusoids show disintegration in a similar way and at the same time as the splenic macrophages during the phase of massive cell destruction (arrow). Hematoxylin \& Eosin,

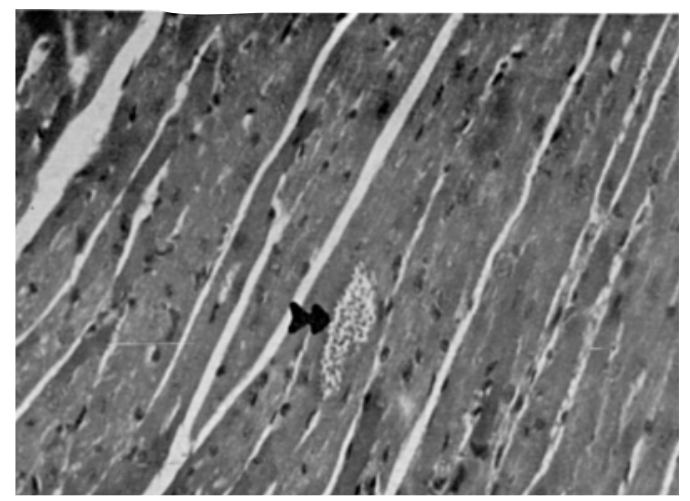

Figure 5 - Section of the myocardium showing a large well preserved amastigote collection inside a myocyte. There is no reaction within the myocardial area seen in this picture. Hematoxylin \& Eosin, $160 X$.

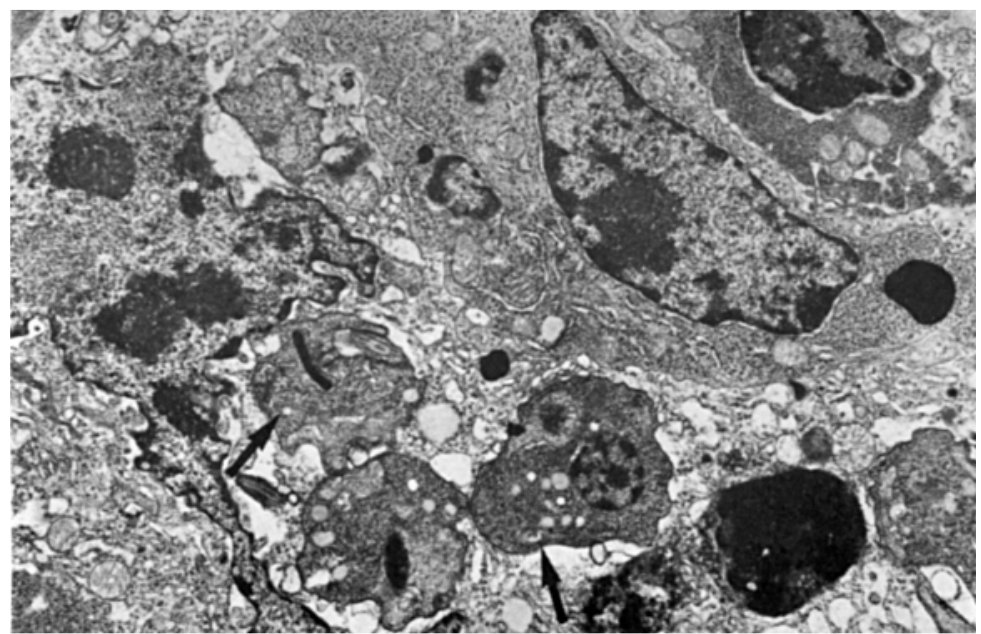

Figure 6 - Electron micrograph showing disintegrating amastigotes within a vacuolated splenic cell cytoplasm. The parasites exhibit an irregular outline, condensation and vacuolation of the cytoplasm, tumefaction of the mitochondrial-kinetoplasm apparatus and picnosis (arrows). 7,00OX.

depletion was not a striking feature as in the previous cases. Accumulation of plasmocytoid and other basophilic lymphoid cells appeared at several scattered foci within the red pulp. Focal accumulation of macrophages, sometimes with a micro-granulomatous structure, was also observed. The marginal zone and the lymph follicles became more apparent, suggesting a returning to the normal splenic structure. However, a few clear, empty areas were present within the red pulp, suggesting the dropping out of splenic cells.

The spleens taken from treated mice were essentially within normal limits and no parasites were seen within macrophages or elsewhere in the spleen after 5 days of 
Cordeiro ZMS, Dabia ACG, Andrade ZA. Kinetics of Trypanosoma cruzi destruction in the mouse spleen. Revista da Sociedade Brasileira de Medicina Tropical 30:3-9, jan-fev, 1997.

benznidazole treatment. Parasites were detected in other organs within muscle cells, but not in macrophages.

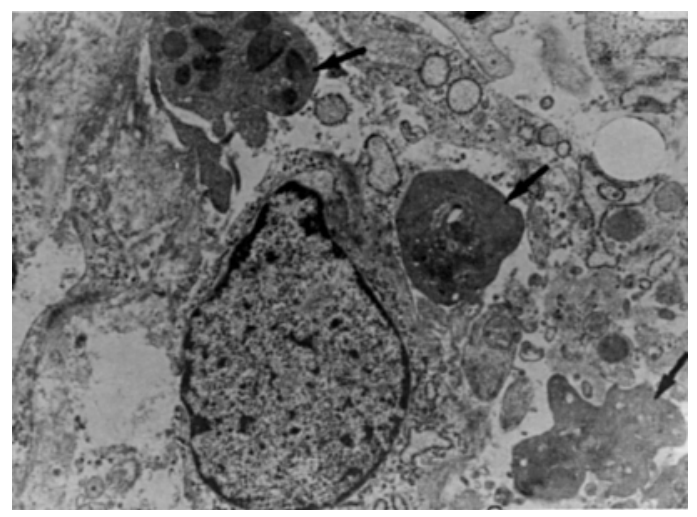

Figure 7 - Partially degranulated platelets (arrows) appeared frequently within the splenic capillaries, as shown in this electron micrograph. 7,000X,

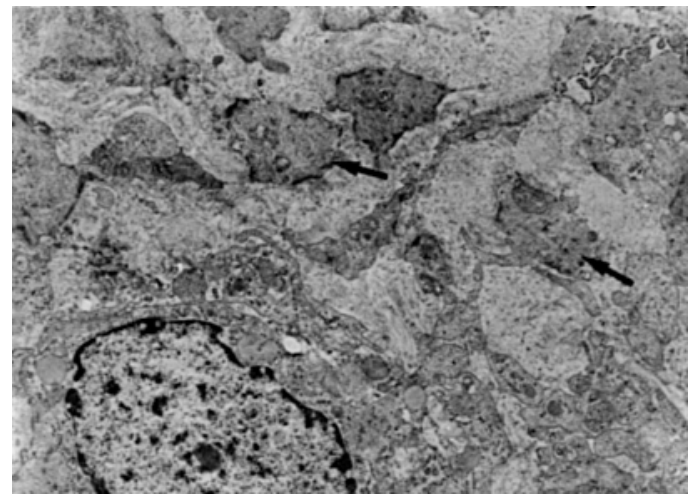

Figure 8 - Focal proliferation of fusiform connective cells, identified as myofibroblasts, seen in the spleen of a mouse during the phase of massive parasitized macrophage disintegration. Electron Micrograph, 4.400X.

\section{DISCUSSION}

Sequential observation of splenic changes during a virulent $T$. cruzi infection in the mouse revealed that parasitism of splenic macrophages progressed up to a point of massive involvement and then, suddenly, there was a diffuse destruction of parasitized cells and parasites. Significance of this finding involves immunologic and pathogenetic aspects of great importance. Immune destruction of infected cells probably means the expression of foreign antigen(s) in the macrophage external membranes. Such antigens are then a target to sensitized cytotoxic lymphocytes, specific antibodies, and/or antibody-mediated cell citotoxicity. Why the destruction occurred suddenly is a matter probably related to the reaching of an equivalence or critic point amongst immunologic factors ${ }^{15}$.

This would mean that the host became strongly immune, but paradoxically this transition is often fatal, probably due to the liberation of toxic products by the disintegrating cells. One of such product could well be TNF (tumor necrosis factors), since it is synthesized in great amount by macrophages parasitized by $T . c r u z i^{13}$ and has been hold responsible for generalized toxic symptoms and even shock ${ }^{10}$. Eventual disintegration of parasitized macrophages occurring before the episode of massive cell destruction may depend on a different pathogenesis, since the host reaction was then limited to a focal infiltration by polymorphonuclear leukocytes. Similar findings observed in the connective tissue of mice have been correlated with local antigen-antibody reaction and hypocomplementemia ${ }^{12}$.

Macrophages are probably the first cells to be infected by $T$. cruzi. Trypomastigotes entering or being phagocytized by naive macrophages readly escape from the phagocytic vacuole and get into the cell cytosol, where they successively multiply as amastigotes. However, if macrophages are stimulated by sensitized T-cell lymphocyte soluble products, they become able to rapidly destroy internalized trypomastigotes ${ }^{67}$. These early events are crucial and may determined the outcome of the infection ${ }^{14}$. Suppressive chemotherapy accelerates this transitional phase and thus allows for a direct passage to the chronic stage, as has been demonstrated here and by others ${ }^{3}$. Probably, the elimination of parasites from the spleen would expose adequate antigens to the immune system and/or would interferes with the generation of suppressive splenic cells or other suppressive factors ${ }^{4}$.

Findings observed in two animals that apparently survived the critical period of massive parasitized-cell destruction are suggestive that reconstitution of splenic structure may be quite rapid and complete. That capacity for regeneration shown by the spleen is in 
Cordeiro ZMS, Dabia ACG, Andrade ZA. Kinetics of Trypanosoma cruzi destruction in the mouse spleen. Revista da Sociedade Brasileira de Medicina Tropical 30:3-9, jan-fev, 1997.

keeping with observations made in other lymphoid tissues ${ }^{8}$.

\section{RESUMO}

Um estudo bistologico sequenciado mostrou que o parasitismo dos macrófagos esplênicos por uma cepa virulenta (cepa $Y$ ) do Trypanosoma cruzi tem um curso progressivo, mas chega até um ponto em que todos as células parasitadas são subitamente destruídas. Tal achado coincidiu com uma quéda brusca da curva parasitêmica e com a morte da maioria dos animais, provavelmente devido à liberação de produtos tóxicos (como o TNF) pelas células desintegradas. O achado foi interpretado como o auge da transição entre uma fase de susceptibilidade e outra de resistência. Embora esta transição tenha sido bem estudada in vitro, este estudo contribui com os dados do substrato morfológico observados in vivo, através da microscopia ótica e eletrônica. O tratamento específico e supressivo feito na fase inicial da infecção acarreta uma transição imediata para a fase crônica e aí o parasitismo esplênico desaparece completamente. Os animais que aparentemente se recuperaram expontaneamente após a fase de destruição maciça dos macrófagos parasitados exibiram evidências de que a reconstituição da estrutura esplênica pode se fazer rapidamente.

Palavras-chaves: Trypanosoma cruzi. Macrófagos. Baço.

\section{REFERENCES}

1. Andrade SG. Morphological and behavioural characterization of Trypanosoma cruzi strains. Revista da Sociedade Brasileira de Medicina Tropical 18: 39-46, 1985.

2. Andrade ZA, Paiva A. Reações imunocelulares na tripanosomíase cruzi experimental. Revista Médica da Bahia 18: 27-33, 1962

3. Brener Z. Contribuição ao estudo da terapêutica experimental da doença de Chagas. Tese de Docência Livre, Facudade de Odontologia e Farmácia da Universidade de Minas Gerais, Belo Horizonte, MG., 1961.

4. Hoft DT, Lynch RG, Kirchoff LV. Kinetic analysis of antigen-specific immune responses in resistant and susceptible mice during infection with Trypanosoma cruzi. Journal of Immunology 151: 7038-7047, 1993.
5. Maria TA. A resposta do baço na doença de Chagas murina experimental: estudo ao microscópio eletrônico. Tese de Doutorado, Universidade Federal de Minas Gerais, Belo Horizonte, MG 1987.

6. Nogueira N, Cohn Z. Trypanosoma cruzi: mechanism of entry and intracellular fate in mammalian cells. Journal of Experimental Medicine 143: 1402-1420, 1976.

7. Nogueira N, Cohn Z. Trypanosoma cruzi: in vitro induction of macrophage microbicidal activity. Journal of Experimental Medicine 148: 288-300, 1978.

8. Oliveira Filho J, Andrade ZA. Stromal collapse in acute atrophy of lymphoid organs. Experimental and Toxicologic Pathology 46: 81-85, 1994

9. Pizzi T, Knierin F. Modificaciones del baso en relación con la tasa de anticuerpos circulantes en ratones experimentalmente infectados con Trypanosoma cruzi. Bolletin Chileno de Parasitologia 10: 42-52, 1955.

10. Playfair JH, Taverne J. Anti-parasite effects of tumor necrosis factor in vivo and in vitro. Ciba Foundation Symposium 131: 192-205, 1987.

11. Rego SFM. Estudo das lesões provocadas pelo Trypanosoma cruzi, Chagas 1909, no baço e fígado de camundongo branco (Mus musculus) com diversos graus de resistência. Tese de Doutorado, Faculdade de Medicina de Ribeirão Preto, Ribeirão Preto, SP, 1957.

12. Silva JC, Pirmez C, Morgado MG, Galvão Castro B. Immunopathological aspects of experimental Trypanosoma cruzi infection: correlation of immune complexes and other serological festures with muscle lesions during infection. Parasite Immunology 7: 457-466, 1985.

13. Tarleton RL. Tumor necrosis factor (cachectin) production during experimental Chagas disease. Clinical and Experimental Immunology 73: 186190, 1988.

14. Tarleton RL, Scott DW. Initial induction of immunity followed by suppression of responses to parasite antigens during Trypanosoma cruzi infection of mice. Parasite Immunology 9: 579$589,1987$.

15. Unanue ER, Allen PM. The basis for the immunoregulatory role of macrophages and other accessory cells. Science 236: 551-557, 1987. 